Editorial material published herein is the property of AECT unless otherwise noted. Opinions expressed in TechTrends do not necessarily reflect the official position of AECT. All artwork (C) Ned Shaw except where noted.

Permissions: Copyrighted material from TechTrends may be reproduced for noncommercial purposes provided full credit acknowledgement and a copyright notice appear on the reproduction. Other requests for reprinting should be addressed to AECT Permissions.

Trademark Notice: Product and corporate names may be trademarks or registered trademarks and are used only for explanation and to the owner's benefit, without intent to infringe.

For advertising rates and deadlines, contact the AECT offices, 812-335-7675.

Subscription information: TechTrends is published six times per year by Springer Science+Business Media, LLC., Volume 52 (6 issues) will be published in 2008.

ISSN: 8756-3894 (print version)

Subscription Rates, Orders, Inquiries: Please contact our Customer Service department for the latest rates and information:

The Americas (North, South, Central America, and the Caribbean):

MAIL: Journals Customer Service

P.O. Box 2485

Secaucus, NJ 07096, USA

TEL: 800-777-4643; 212-460-1500

(outside North America)

FAX: 201-348-4505

E-MAIL: journals-ny@springer-sbm.com

Outside of the Americas:

MAIL: Journals Customer Service

Springer Distribution Center (SDC)

Haberstr. 7

69126 Heidelberg, GERMANY

TEL: 49-6221-345-4303

FAX: 49-6221-345-4229

E-MAIL: sdc-journals@springer-sbm.com

Change of Address: Allow six weeks for all changes to become effective. All communications should include both old and new addresses (with zip codes) and should be accompanied by a mailing label from a recent issue.

Back Volumes: Prices for back volumes are available on request.

Microform Editions: Available from:

University Microfilms International, 300 N. Zeeb Road, Ann Arbor, MI 48106, USA

SpringerAlerts Service: The SpringerAlert service is an innovative, free-of-charge service that notifies users via e-mail whenever new SpringerLink articles and journals become available, and automatically sends the table of contents and direct links to the abstracts of a new issue of a journal in SpringerLink. Register for the SpringerAlert service at http://www.springerlink.com/alerting
Guest Editor's Notes

\section{Honoring Lida Cochran}

\author{
Rhonda S. Robinson, PhD \\ Northern Illinois University \\ Educational Technology, \\ Research and Assessment Department
}

\section{I}

can not remember when I first met Lida Cochran, but I believe it was very early in the 1980s when I first became active in the International Visual Literacy Association. Fellow UW-Madison doctoral students in Educational Communications, studying then with Dr. Ann DeVaney, introduced me to IVLA and encouraged me to attend my first conference in Lexington, KY, in 1980. I was studying film and television and considering the aesthetic and narrative elements of those media and their impact on K12 school students. I became active in IVLA almost immediately at the invitation of long-time member Jim Sucy, who asked me to assist him in promoting the next conference in Bloomington, IN. I was hooked on the small, friendly, diverse, and multidisciplinary organization and its amazing members.

I have several favorite memories of Lida. These selected three help define her as a mentor, a scholar, and a service-oriented professional. The first involves a conversation I had with her at an AECT conference in the early 1980s when we were discussing my next research project. While we barely knew one another, she seemed so interested in hearing my ideas. When I mentioned to her that I was considering critically examining the early educational films produced to help teach- ers learn about technology, she immediately offered to have me come to her home, stay a weekend, and review the entire collection of early educational film journals stored in her basement! Lida was full of enthusiasms and she effortlessly mentored many new IVLA and AECT members like me. Her support was intellectual, non-judgmental, and freely offered. While she challenged the thinking of her many new friends, she always suggested assistance as well.

The second involves Lida's continuing scholarship on the definition and meaning of visual and verbal literacy. As part of that continuing initiative, Lida planned a symposium for the 1990 IVLA Conference to discuss the evolution of the definitions of visual literacy. Recognizing that Lida herself was an expert on this topic and that she had been among the group that coined the term visual literacy, those of us selected for the panel were challenged by her invitation. Lida facilitated the panel discussion with a clock or stopwatch in hand to insure the time limits she had set were maintained. She had, of course, invited a very diverse and well-informed group to speak and debate, and the articles coming out of that panel helped move the IVLA forward on the understanding of the definition. She continued her scholarship on several topics throughout her 
life, and encouraged many of us to continue to think, read, illustrate, and consider the meaning of visual literacy.

A third memory is an image I wish I could show rather than explain. I cochaired (with IAECT) the IVLA Conference in Chicago and Lida was one of the speakers introduced at a meal event. She had requested a box in order to be seen above the podium, but was not disconcerted by our lack of foresight. She stood on that box, introduced herself, and told us a story about IVLA and our financial hardships that year. She then announced that since she seemed not to have further need for her car, at her age, she was donating the value of the car once sold to IVLA. Her generosity and support of professional organizations with time, finances, and ideas were boundless. The AECT Foundation members know this to be true.

Mentor, scholar, service-oriented professional: these all describe Lida and her amazing life. She was also a pioneer as a woman; and in visual literacy development and the IVLA, an amazing artist in photography and poetry; a talented video producer; an inveterate traveler; and a socially conscious volunteer for many causes. She was intellectually curious and a true lifelong learner.

While Lida is loved and missed by many colleagues and friends, this issue of TechTrends is dedicated to her life and work. We present several articles which share ideas and projects from a variety of perspectives, honoring the breadth of Lida's interests. We selected these as examples of the many authors and scholars continuing the work Lida started. The International Visual Literacy Association members and friends invite you to review and consider these articles as they help illustrate the development and point towards the future of visual literacy.

As special topic issue editor, I acknowledge the assistance and support from the others involved: Dr. Maria Avgerinou, DePaul University, who coordinated the review process; the article reviewers, including Drs. Janet Giesen,
NIU; Patricia Search, Rensselaer Polytechnic Institute; and Maria Avgerinou; and the editors at TechTrends, Dr. Sharon Smaldino and Jean Callary.

The International Visual Literacy Association invites you to consider membership in our organization, which provides a forum for the discussion of the principles and applications of visual literacy. Join others in a multidisciplinary association dedicated to investigating and promoting visual literacy, communications, education, and aesthetics in a congenial and scholarly approach to this vital area of study.

Help uncover, discover, create, and promote the many aspects of visual learning and literacy with an interesting, friendly, and curious group of professionals. Membership benefits include an annual conference with an international location every three years and refereed selected readings from each conference; the scholarly Journal of Visual Literacy, published twice a year; and a regular newsletter and blog conversation (ivla.org).

\section{Check Out These Routledge Titles!}

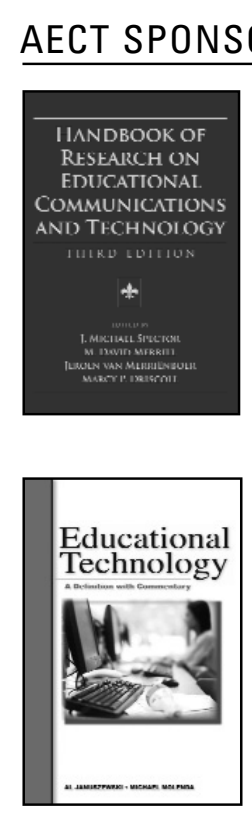

ORDERING OPTIONS

Mail to: 7625 Empire Drive, Florence, KY 41042

Call toll free: 1-800-634-7064 - Call international: 859-525-2230

Fax toll free: 1-800-248-4724 - Fax international: 859-647-5027 - Web address: www.routledge.com

PLEASE VISIT WWW.ROUTLEDGE.COM/EDUCATION FOR MORE INFORMATION ON THESE AND OTHER EDUCATION BOOKS PUBLISHED BY THE TAYLOR \& FRANCIS GROUP.
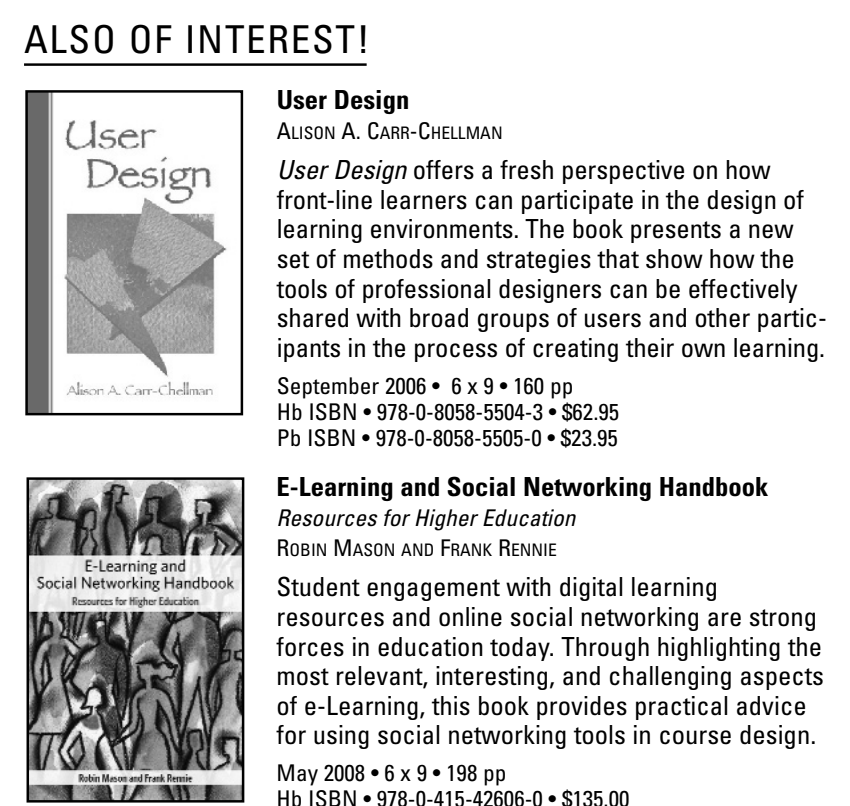

\section{E-Learning and Social Networking Handbook}

Resources for Higher Education

Robin Mason and Frank Rennie

Student engagement with digital learning resources and online social networking are strong forces in education today. Through highlighting the most relevant, interesting, and challenging aspects of e-Learning, this book provides practical advice for using social networking tools in course design. May $2008 \bullet 6 \times 9 \bullet 198 \mathrm{pp}$ $\mathrm{Hb}$ ISBN • 978-0-415-42606-0 • \$135.00 $\mathrm{Pb}$ ISBN • 978-0-415-42607-7 • \$41.95 